International Review of Research in Open and Distributed Learning Volume 17, Number 4

June - 2016

\title{
Increasing Access to Higher Education Through Open and Distance Learning: Empirical Findings From Mzuzu University, Malawi
}

Winner Dominic Chawinga and Paxton Andrew Zozie

Mzuzu University, Malawi

\begin{abstract}
Slowly but surely, open and distance learning (ODL) programmes are being regarded as one of the most practical ways that universities across the world are increasingly adopting in order to increase access to university education. Likewise, Mzuzu University (MZUNI) set up the Centre for Open and Distance Learning (CODL) to oversee the running of these programmes in 2011. In this study, we adopted the Transactional Distance Theory (Moore, 1997) to investigate the modes of instructional systems, benefits or opportunities, and the challenges associated with the delivery of ODL programmes at MZUNI. By selfadministering a questionnaire to 350 ODL students and 9 Heads of Department in the Faculty of Education whose programmes are offered through ODL, we found that instructions are mostly delivered to students through print-based instructional materials. The major benefits noted include increased access to quality higher education, affordable tuition fees, and flexibility in payment of fees. However, we established some challenges which need to be addressed by the University which include, delayed feedback of assignments and release of end of semester examination results, absence of information for courses of study, poor communication between the Centre and departments, and poor remuneration for lecturers.
\end{abstract}

Keywords: higher education, Malawi, Mzuzu University, open and distance learning, students

\section{Introduction}

The expression "education is key to success" is commonly quoted by many educational experts and researchers. It thus follows that education is supposed to be accessible to everyone regardless of their economic situation. To this end, Article 26 of the United Nations (1948), proclaims that "higher education shall be equally accessible to all on the basis of merit" (p.5). Similarly, Article 13 of the United Nations (1966) stipulates that "higher education shall be made equally accessible to all, on the basis of capacity, by every appropriate means, in particular by the progressive introduction of free education" (p.6). However, 
developing countries, such as Malawi, are still struggling to provide higher education to deserving students. A group of researchers (Badat, 2004; Bekhradnia, 2004; Brennan, 2004; Smith \& Casserly, 2006) have all independently observed that inequalities of access to higher education, still exist around the world. In Africa, especially Southern Africa, the Southern Africa Regional Universities Association (2011) reports that access to higher education is said to be so low and disturbing. The Southern Africa Regional Universities Association (2011) highlights a range of challenges that are directly responsible for the poor status of higher education in Southern Africa. The challenges include: reduced funding by governments to public universities and other institutions of higher learning which are deemed to be more affordable than private universities; rise in competition for donor funding amongst private and public universities; increase in the number of students needing university education; and inefficiency in the use of the available resources by higher education institutions. Perhaps due to the aforementioned factors, the Commonwealth of Learning (2002) reports that "none of the countries in Sub-Saharan Africa have fulfilled the promise of providing education to the entire population through the conventional education system" (p.5). In other words, universities in Southern Africa including Malawi, are unable to admit all deserving individuals on a campus face-to-face or residential basis. To ensure that they remain relevant and survive in the torrent environment in which they operate, Wilson (2008) observes that most universities have resorted to introducing ODL programmes which are believed to be helping them reduce the pressure of the growing number of students. Through ODL, "colleges, universities, businesses, and organisations worldwide now offer their students fully accredited online degree, vocational, and continuing education programmes in abundance" (Mbatha \& Naidoo, 2010, p.68).

According to Garrison (2000) and United Nations Educational, Scientific and Cultural Organisation (UNESCO) (2003), two principal interlocking factors are directly responsible for the flourishing of ODL. They include the desire by individuals to upgrade their skills and current qualification and the unparalleled innovation and advancements in technologies which have effectively cleared the road blocks impeding access to education which previously, was only accessible through classroom based-learning. Most ODL learners have professional responsibilities (jobs), social responsibilities (families), are interested in part time studies, lack of access to on-campus based studies or are away from formal education (Akintayo \& Bunza, 2000) and ODL becomes the readily available option for them to upgrade their qualifications. Realising the promises that come along with ODL, MZUNI is one of the institutions of higher education in Southern Africa which runs ODL programmes. Thus, with specific focus at MZUNI, this study sets out to investigate the opportunities and challenges associated with the implementation of ODL at this institution.

\section{Context of the Study: Centre for Open and Distance Learning at MZUNI}

Concerned with low human resource capacity in the country, MZUNI was established by the Malawi Government through an Act of Parliament in 1997, becoming a second Public University located in the Northern Region of Malawi (Mzuzu University, 2015). Since its first intake in 1999, the University has steadily grown from a single Faculty of Education to four more faculties which include Environmental Sciences, Tourism and Hospitality Management, Information Science and Communications, and Health Sciences. The University also has four centres, namely; the Centre for Open and Distance Learning, the 
Centre for Water and Sanitation, the Centre for Security Studies, and the Testing and Training Centre for Renewable Energy and Technologies (Mzuzu University, 2015, p. 7). Despite efforts to increase access to university education, Mzuzu University (2015) reports that the University's intake has only grown from its first intake of 60 in 1998 to 3,590 students as of 2014. To pursue the dream of expanding access to tertiary education to as many Malawians as possible, MZUNI introduced ODL programmes.

According to Chimpololo (2010), ODL is a relatively new concept in institutions of higher learning because previously, it was mainly practiced at secondary school level. MZUNI established the Centre for Open and Distance Learning (CODL) and according to Chimpololo (2010) and Mzuzu University (2014), the Centre was established in July 2006 to plan, prepare, and coordinate the offering of programmes through open and distance learning delivery modes. The Centre was established with the sole aim of providing university education to qualified Malawians who are not admitted into higher learning institutions due to inadequate space and/or limited teaching and learning. Upon its establishment, the Centre indicated that it could use various delivery modes including "print media, radio, television, multimedia, Internet-based media, and web-technology" (Mzuzu University, 2014). In order to smoothen its operations and increase intake of ODL students, Gwede (2014) highlights that MZUNI seeks partners who can help with the development of technological infrastructure, setting up of satellite centres, and repackaging of print instructional materials into portable audio and visual versions so that learners can listen and view lectures at their pace or time convenience by using computers or mobile technologies. A call for support by the University is in all probability justifiable because according to the United Nations Development Programme (UNDP) Human Development Report (2014), Malawi is one of the poorest countries in the world and it is ranked 174 out of 182 on the Human Development Index.

\section{Problem Statement and Research Questions}

Since independence from Britain some 50 years ago, the Malawi Government has made sound initiatives to develop human capacity through the establishment of a number of vocational and tertiary educational institutions which include, teacher training, technical, nursing, agricultural colleges, and more importantly, universities. However, it is understood that access to tertiary education in Malawi remains very low due to acute shortages of teaching and learning resources, inadequate classrooms and library spaces, and a shortage of human capacity. Some well deserving students are commonly not admitted into universities due to the aforementioned factors. For example, in 2008, public universities in Malawi (Mzuzu University and University of Malawi) then, admitted only 0.03\% of the eligible students using face-to-face and residential delivery modes (Mzuzu University, 2014). Such developments seem to have stimulated MZUNI to introduce ODL programmes. MZUNI envisaged that the Open and Distance Learning delivery mode could provide an opportunity for people to study while working. For example, under-qualified teachers who are already employed in secondary schools would get a chance to upgrade their academic and professional qualification through the open and distance learning mode. The possible challenges for ODL delivery, especially in resource-challenged countries such as Malawi, may include: (i) provision of support to students during home-based study; and (ii) the distance between students' homes and MZUNI for face-to-face delivery of courses and examinations, which may place financial burden on students. One wonders how the university has been fairing since the inauguration of the ODL programmes as it seems there has not been any empirical studies to shed light about the successes or challenges of the open and distance learning mode at MZUNI. Although the Centre is considerably new, it 
is possible to speculate that the University has registered some successes, and possibly, some challenges. In this study, we investigate these possible opportunities and challenges. To achieve this, the study answers the following questions:

- What are the modes of instructional systems of ODL programmes at Mzuzu University?

- What are the benefits or opportunities associated with the introduction of ODL programmes at Mzuzu University?

- What are the challenges associated with delivery of ODL programmes at Mzuzu University?

\section{Literature Review}

Distance education has been in existence for hundreds of years and it is understood to have been conceived in Europe. Bower and Hardy (2004) postulate that "higher education has provided students with distance learning opportunities for over 150 years" (p.5). Modern literature is replete with definitions of ODL. Some put emphasis on technologies while others focus on the aspect of distance. For example, whereas Greenberg (1998) sees contemporary distance learning as a planned teaching/learning experience that uses a wide spectrum of technologies to teach learners at a distance, Teaster and Blieszner (1999) define ODL as primarily, learning and teaching where the teacher and the learner are separate in space and possibly in time. In other words, ODL maybe basically seen as the type of teaching and learning which does not involve face-to-face interaction between the learner and the teacher although, according to Holmberg (2005), "in other cases, supplementary, face-to-face sessions can be useful for distance students" ( $p$.14). Valentine (2002) emphasises that although the teacher and the learner are truly separated by space, this does not apply to time.

It is worth emphasising that previously, the dominant term used in this type of learning was distance learning (DL). The inclusion of an adjective "open" was, according to Holmberg (2005), as a result of a "strong influence of the British Open University where 'open' originally referred to access and to the avoidance of certain restrictions" (p. 5). It seems most scholars judge ODL based on the term open learning offered by the Open University UK which seems to be a fairly common meaning. At the Open University UK, the true meaning of "open" is that, "the institution has no barriers to entry, no entry requirements-only exit standards; a person's background and previous advantage or disadvantage is entirely irrelevant" (Gourley \& Lane, 2009, p. 57). In sum, Kudryavtseva (2014) sees ODL as a way of providing learning opportunities that is characterised by the separation of teacher and learner in time or place, or both time and place. This author also points out the use of a variety of media, interactive communication, the possibility of occasional face-to-face meetings, and a specialised division of labour in the production and delivery of courses. A review of literature further shows that there are several reasons universities are opting for ODL programmes. Swanepoel, De Beer, and Muller (2009) make it very clear that "distance education provides opportunities for developing countries such as South Africa and other African countries to realise their educational goals" (p. 312).

Valentine (2002) reports that before the advent of Internet technologies, distance education was mainly delivered via radio and television in addition to sending audio tapes and by sending lessons through the 
mail. The Open University UK, which has led the way and perhaps set the standards for ODL, offers its content in both print and electronic forms. According to Gourley and Lane (2009), apart from making its published materials public for students and the public to buy, "the Open University UK had a powerful partnership with the British Broadcasting Corporation (BBC) for several decades where lectures were broadcast to the public across the world" (p. 57). As already noted above, the introduction of the Internet has revolutionised the way institutions, especially universities, deliver credit and non-credit distance courses to students. Bower and Hardy (2004) and Kudryavtseva (2014) demonstrate that the Internet, through its ability to offer both asynchronous as well as synchronous activities, has become an excellent platform for conducting distance education through chat sessions and online discussions which can be used to engage learners in student-to-student, as well as, student-to-instructor interactions. This is perhaps the reason Kudryavtseva (2014) identifies the Internet as "one of the facilities necessary for the effective delivery of lessons in ODL programmes" (p .1217). Likewise, Ekwunife-Orakwue and Teng (2014) argue that "modalities of distance learning that leverage interaction, and allow seamless experiences with technologies will continue to thrive and proliferate" (p. 425).

In India, Aslam (2000) reports that universities have taken advantage of modern communications technologies by introducing audio-video programmes that supplement print materials. Audio-video materials are commonly preferred in the delivery of ODL programmes because according to Aslam (2000), they add an interactive element to the package, and help students optimise their learning skills. A recent study was conducted by Kritpracha, Kaosaiyaporn, and Atisabda (2015) who investigated the expectation of administrators, teachers, education officers, and students towards a distance learning model in southernmost provinces of Thailand. The researchers (Kritpracha, Kaosaiyaporn, \& Atisabda, 2015) found that for distance learning to be successfully delivered, it should be organised based on the needs of the learners and that access to learning materials by students should not be restricted to time or place. Similarly, Abimbola, Omolara, and Fatimah (2015) report about on the impact of ODL in enhancing the status of women in Lagos State, Nigeria. The authors (Abimbola, Omolara, \& Fatimah, 2015) find that ODL significantly improved the status of women in Lagos State of Nigeria by offering them access to various forms of information that enabled them understand their rights and entitlements in society, including acquiring better communication skills that has changed their political, social, economic, and cultural status.

Literature shows that there are several benefits that institutions offering ODL programmes reap. The benefits range from students' perspectives to individual institution's perspectives. As already stated in the previous sections, the very basic concept of ODL is now very clear; an arrangement by the university to deliver education to a student cohort that is geographically separate from the tutors or lecturers is the main objective of ODL. Lentell (2012) observes that such an arrangement enables institutions to provide quality education to learners who are rarely, if ever, on a campus. ODL programmes provide an opportunity to learners in remote locations who, because of other factors, may not be able to register for residential-based lessons. There is no doubt that the introduction of ODL has eased pressure on universities to meet the demand of the increasing number of students in need of university education. Over the years, the number of people applying for university education has increased, yet the universities do not have capacity to accommodate all these students. Thus, the Commonwealth of Learning (2003) puts a strong argument that "open and distance learning can expand the limited number of places 
available for campus-based institutions which are few in numbers and have stringent entrance requirements" thereby making higher education accessible to the majority of the world. In summary, there are four key advantages that have propelled the growth of ODL programmes over the years according to Perraton (2000): 1) they have lessened pressure to build school buildings, 2) they have reduced the number of teachers and school administrators, 3) they allow people with jobs an opportunity to learn while keeping their jobs, and finally (4), they know no boundaries as they can be offered over long distances and cater for widely scattered students.

Some recent studies have attempted to compare face-to-face and ODL programmes. Réka, Kármen, Susana, Kinga, Edit and Kinga (2015) investigated the relationship between the type of education (fulltime and distance) in terms of academic performance and motivation at a Romanian-based university. The authors report that ODL programmes outweigh face-to-face programmes in relation to student motivation. While distance learners exhibit a higher level of intrinsic motivation, full-time learners are more extrinsically motivated (Réka, et al., 2015). In the same vein, using Michael Moore's transactional distance theory, Mbatha and Naidoo (2010) investigated the availability and use of e-learning resources by Communication Science Students at the University of South Africa (UNISA). The authors found that one of the advantages of ODL is that "the students control the learning environment because they can decide when and where to learn and how long to take over a course” (p.66).

Although the literature shows that there are quite a number of opportunities and promises that come along with the adoption of ODL by universities, it is not short of controversies and challenges. Valentine (2002) identifies several challenges that impinge the implementation of ODL programmes. He observes that "much of the instruction depends on the attitude of the administrators and instructors" (para. 8). In this case, some ODL stakeholders especially administrators regard distance education as of low quality as compared to face-to-face lessons. Sherritt (1996) and Commonwealth of Learning (2002) indicate that some administrators, who are key decision makers, perceive ODL as second grade programmes. There is no doubt that such perceptions may affect the successful implementation of ODL programmes. This is the reason some researchers such as Lentell (2012) have strongly advocated the need for continued and unconditional support from university managements for ODL programmes to hold their ground and to remain sustainable. Another challenge that affects the adoption of ODL in developing countries is poor information technology infrastructure (Atkins, Brown, \& Hammond, 2007; Wilson, 2008). "The availability and reliability of ICTs which are crucial to the success of ODL in modern times have remained unequal between different countries" (Wilson, 2008, p.2). Internet has always been a problem in most African countries and, according to Atkins, Brown, and Hammond (2007), Internet access is not widely available and tends to be situated in large cities rather than rural areas. On a positive note though, recent reports by the International Telecommunication Union (2014) shows that the number of Internet users in Africa has grown steadily, from $6 \%$ in 2008 to $16 \%$ in 2013 . One may therefore expect many universities to utilise the steady permeation of the Internet to venture into offering ODL programmes.

\section{Theoretical Framework: The Transactional Distance Theory}

The study is underpinned by the Transactional Distance Theory (TDT) (Moore, 1997). In the TDT, the focus is on the cognitive space that exists between instructors and learners in any educational environment. Moore (1980) sees distance education not just as a geographical separation but rather a 
pedagogical concept. That is to say what is commonly or widely perceived as the main problem, that there is a geographical issue for the learner, in actuality, the pedagogical issue is equally important. There are three elements that interplay to shorten the distance between an instructor and a learner (Martindale, 2002) that include: 1) the structure of instructional programmes; 2) the interaction between learners and teachers; and 3) the nature and degree of self-directness of the learner.

\section{The Structure of Instructional Programmes}

Martindale (2002) notes that structure refers to the course, the organisation of the design, and the use of various media of communications. According to Moore (1980), the structure expounds the rigidity or flexibility of the objectives of the educational programme, strategies of teaching, and the methods of evaluating. Thus, it becomes essential that in the process of designing ODL courses, it should be envisaged that the learner may not be accorded an opportunity to meet instructors as is the case with the structure of face-to-face mode of teaching and learning. This implies that poorly designed courses can lead to some challenges to distance learners.

\section{Interaction Between Learners and Teachers or Dialogue}

The aspect of interaction between learners and teachers, also called dialogue is another important element of the TDT theory. Moore (1997) places emphasis on the concept of dialogue and asserts that dialogue is developed by teachers and learners in the course of the interactions that occur when one gives instruction and the others respond. In short, dialogue can be seen as an interplay between an instructor and a learner within the environment in which teaching and learning takes place. Authors such as Martindale (2002) argue that it is not actually the location that determines the effect of an instruction but rather it is the interaction between the instructor and the learner. It is actually the course designers, the personalities of teachers, the subject matter of the course, and the environmental factors that determines the interactions (Martindale, 2002). Again, poor structure of the course, inappropriate media of communication, and ineffective feedback can negatively affect the efficiency of interaction process in ODL which can consequently lead to negative effects on teaching/learning experiences.

\section{Self-Directness or Autonomy of the Learner}

The last variable from TDT is self-directness or autonomy. This refers to "the extent to which in the teaching/learning relationship the learner rather than the teacher determines the goals, the learning experiences, and the evaluation decisions of the learning programme" (Moore, 1997). Autonomy is very important because to a large extent, it is commonly known that ODL students rely on their own sense of personal responsibility and self-directness. In fact, Garrison (2002) states that the learner's capacity has a lot to do with personality, learning styles, prior experience, and other factors, including the content to be taught. Thus, structure of the courses such as rigidity of the course, an inappropriate media of communication, and dialogue can negatively affect learners' self-directness.

The TDT is perceived as most relevant for this study because it has previously been successfully used in similar studies (Bitegeko, 2010; Mbatha \& Naidoo, 2010; Goel, Zhang, \& Templeton, 2012) with credible results being realised. Specifically for this study, the Theory makes concrete reference in bridging the transactional gap in an ODL environment. For example, for ODL students to succeed, there is need to examine how flexible the courses or programmes are structured, how the opportunity for dialogue is made 
available between the instructor and learner regardless of the physical distance, as well as how the student is equipped to take control of the learning process considering that the student meets the instructor once in a while.

\section{Methodology}

This case study design which employed a mixed methods approach was conducted between January and February, 2015 at MZUNI. The target population that provided data for this study included registered ODL students at MZUNI and Heads of Department in the Faculty of Education. At the moment, MZUNI runs four ODL programmes; Bachelor of Arts (Education), Bachelor of Science (Education), Diploma of Arts (Education), and Diploma of Science (Education). During the time of collecting data, there were no students in Level One implying that the current 750 registered ODL students (Mzuzu University, 2014) are those in levels two, three, and four. The Faculty of Education has nine departments; each of the departments is headed by a Head of Department.

Flyvbjerg (2006) reports that "there are no theories and universals that can consistently predict the human affairs in different contexts” (p. 224), hence case studies are said to provide and produce concrete and context dependent knowledge of a phenomenon. To this end, this study adopted a case design because the researchers wanted to effectively have a deep understanding about the status of ODL programmes at MZUNI in terms of instructional systems used, benefits or opportunities, and challenges associated with delivery of ODL programmes at MZUNI. In collecting data, a "questionnaire" (Connaway \& Powell, 2004, p. 146) was used. Methodologically, our study was informed by similar prior studies. For example, our decision to use a questionnaire as a data collection instrument was arrived because similar studies by Mbatha and Naidoo (2010), Goel, Zhang, and Templeton (2012), Al-Arimi (2014), Kudryavtseva (2014), Ekwunife-Orakwue and Teng (2014), Kritpracha, Kaosaiyaporn, and Atisabda (2015) and Réka et al. (2015) successfully used a similar data collection instrument. Since the researchers targeted quite a large number of students, a questionnaire was seen as an effective way of collecting data from this large population. The researchers took advantage of students' presence on campus in January and February 2015 when they came to write end of semester examinations to distribute a questionnaire. The researchers were of the view that all students, being in those levels, had ideas and personal experiences about the successes and challenges emanating from the ODL programmes at MZUNI. Students from Levels Two to Four were therefore purposively included in the study (Babbie, 2004). In total, a questionnaire consisting both closed-ended and open-ended questions was sent to a total sample size of 350 students. It is only courses from the Faculty of Education that are offered through the ODL and the researchers found it plausible to distribute a questionnaire, consisting of only open-ended questions to all of the nine Heads of Department in the Faculty.

Apart from background information which had six questions, the students' questionnaire had three additional sections (each with a mix of closed-ended and open-ended questions) which included, mode of instructions (five questions), benefits of ODL (three questions), and challenges faced (three questions). The lecturers' questionnaire consisted of nine questions which were all open ended and they gathered data about mode of instruction, benefits of ODL, and challenges faced. Before the commencement of the study, permission was sought from, and granted by the Office of Directorate of Research on behalf of MZUNI. Participation in the study was voluntary and to enforce this, before answering the questionnaire, 
participants were requested and reminded to read the following statement: "I understand that my participation is voluntary and I am free to withdraw at any time without giving any reason." To maintain respondents' privacy and anonymity, participants were not asked to indicate their names. Thus, quantitative data collected using a questionnaire from students was triangulated with qualitative data collected using a questionnaire from Heads of Departments. To ensure validity and reliability of the data collected, the questionnaire content was rigorously perfected through pretesting. In line with Lin (2014), pretesting focused on instrument clarity, question wording, and validity. Pretesting was achieved by distributing students' questionnaire and lecturers' questionnaire to ten ODL students and three lecturers respectively. Experts in the fields of education particularly, ODL were asked to comment on the instrument. Eventually, corrections and refinements were made based on the feedback from the process of pretesting.

Data collected from respondents were organised in order to facilitate analysis by coding quantitative data into numeric data. To achieve this, the Statistical Package for the Social Sciences (SPSS) was used to determine frequencies and percentages. Some frequencies and percentages were imported from SPSS to Microsoft Excel to produce charts and figures. Frequency distributions were depicted in tables and charts. Qualitative data were analysed thematically. Thematic analysis is a method for identifying, analysing, and reporting patterns (themes) within data (Braun \& Clarke, 2006). In this study, thematic analysis was achieved by identifying commonly recurring and prevalent themes which assisted in answering the research questions.

\section{Data Analysis and Discussion of Results}

The results are analysed and discussed below covering background information of respondents, modes of instruction and assessment, benefits of ODL and challenges impeding against operations of ODL.

\section{Background Information}

In total, we sent a questionnaire to 350 students with 233 (66.5\%) responding to the questionnaire. Of these, 191 (82\%) were males and 42 (18\%) were females. Chawinga (2014) asserts that historically, universities in Malawi enrol more males than females mainly because of culture which dictates that females are supposed to get married as soon as they reach the puberty stage. In contrast, males are regarded as breadwinners and are encouraged to work hard in school so that they can support their wives and families. Likewise, of the nine Heads of Department to whom we sent a questionnaire, five responded of whom two were females and three males. Findings presented in Figure 1 below suggest that most students are studying a Bachelor of Arts (Education). Elsewhere, Kritpracha, Kaosaiyaporn, and Atisabda (2015) find that more students were studying arts subjects with a score of 42 (21.0\%) as compared to science subjects which had a score of 35 (17.5\%). From the results, it is clear that arts subjects remain the most dominant subjects offered through ODL. However, the narrowing gap between arts and science subjects gives substance to sentiments by Holmberg (2005) who argues that "although previously, the assumption was that ODL programmes could be efficiently offered for arts subjects only, the use of audio and video recordings, laboratory kits, computer programmes, telephone contacts, and other media have proved that other subjects are teachable and learnable at a distance" (p.14). 
Results show that the main clients of this programmes are Government Primary School Teachers who are also in possession of Primary School Teaching Certificate. The findings are consistent with observations by Akintayo and Bunza (2000) that ODL makes learning convenient for the working class though the findings of the current study show further that there are some students who are currently not employed.

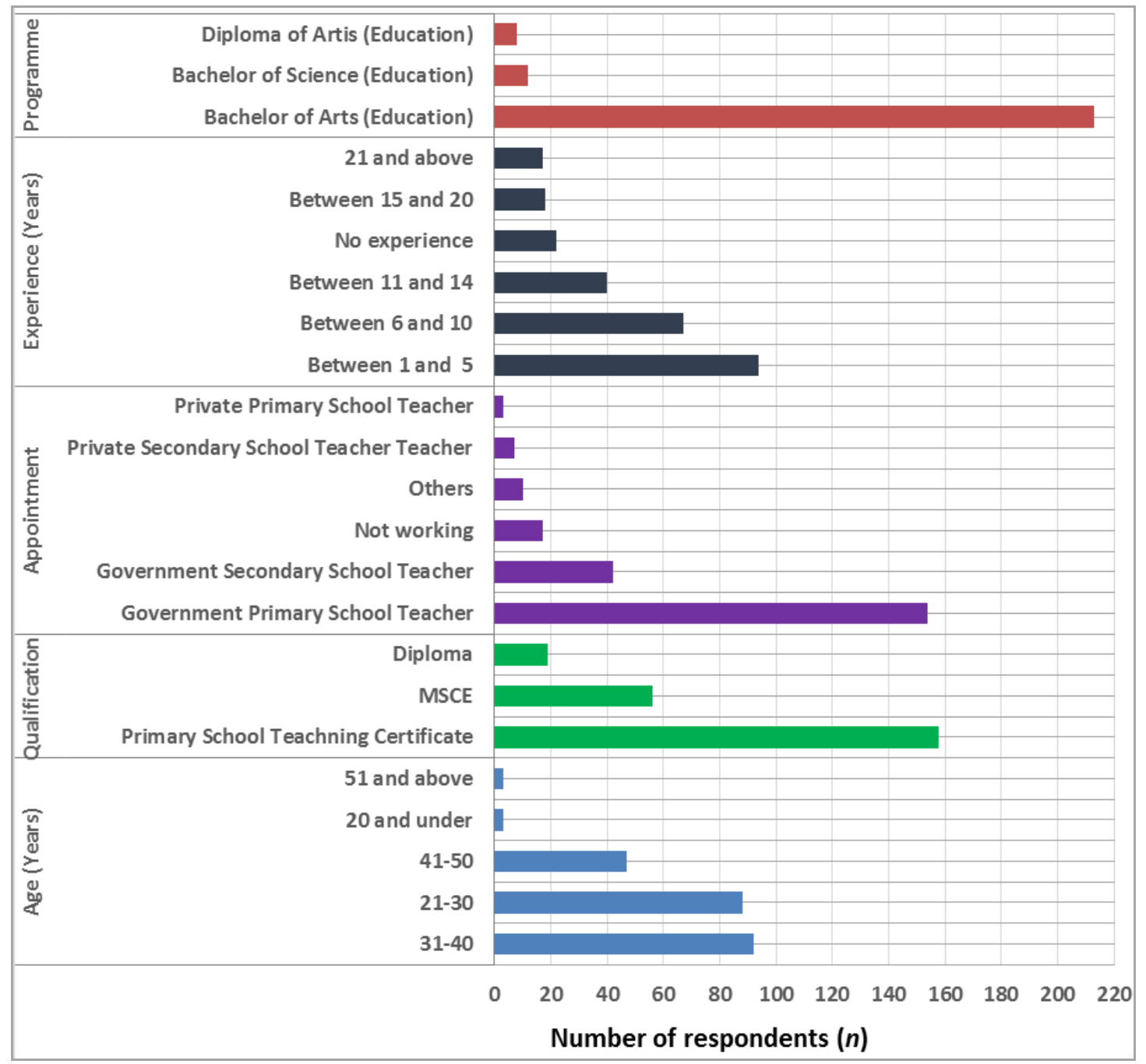

Figure 1. Background information of students' respondents.

\section{Modes of Instruction and Assessment}

Upon establishing ODL, MZUNI indicated that it could adopt various modes of instructional media to deliver content to its students. However, findings from students which are displayed in Figure 2 suggest that the University has not yet adopted technologies such as Internet, radio and TV. This is despite Gourley and Lane (2009) reporting that these technologies are widely used to deliver lessons to ODL students in other ODL universities such as the UK Open University. Rather, MZUNI heavily uses print instructional materials with a score of 222 (95.3\%) followed by the Internet technologies with a score of 57 (24.5\%). Students' results are well corroborated by those of Heads of Department where, all indicated that they mainly use print based particularly, instructional modules to deliver lessons to students. For 
example, one lecturer commented that "lecturers usually provide print modules and assignments to students when they come for orientation or to write end of semester examinations." Since the TDT by Moore (1997) informing this study suggests that the learner may never meet the instructor, the situation is different at MZUNI where the results show that students spend some weeks on campus for three main reasons: to register, for orientation, and to write end of semester examinations. Orientation in this case is very important as it is through this exercise that students are oriented on various aspects including course assessments (i.e., weighting of assignments and end of semester examinations, supplementary examinations, repeating courses and complete withdraws from the University).

It appears that apart from MZUNI, other universities offering ODL programmes also depend on face-toface in the delivery of orientation services to students which, according to Kritpracha, Kaosaiyaporn, and Atisabda (2015) is due to the fact that " $55.3 \%$ students preferred face-to-face orientation as compared to 44.7\%) students who preferred online orientation in the UK" (p. 2353). However, one may suggest that there is no online orientation at MZUNI because of poor ICT infrastructure in Malawi. It has to be borne in mind that the UK is a developed country in terms of technology as compared to Malawi. In fact, Malawi is placed in the category of developing countries and this may be the reason there are such differences in terms of use of technologies in the delivery of instruction via ODL.

Actually, the United Nations Development Programme (UNDP) Human Development Report (2014) indicates that Malawi is a one of the poorest countries in the world and it is ranked 174 out of 182 on the Human Development Index. In addition, Wilson (2008) argues that inequalities in educational achievements between developed and developing countries do exist as a result of vastly different levels of economies. This partially explains why MZUNI is lagging behind in adopting these technologies as modes of delivering instruction to its ODL students. However, with the growth of Internet technologies as reported by the International Telecommunication Union (2014) and with the proliferation of Internet enabled mobile phones in Malawi as reported by Chaputula (2010), the University can explore on how to make use of Internet technologies in delivering lessons to ODL students. After all, other African universities such UNISA in South Africa have intensified the use Internet technologies as evidenced by reports by Mbatha and Naidoo (2010) who report that "98 (89\%) of the students use the Internet for their studies and 92 (87\%) use emails" (p.66).

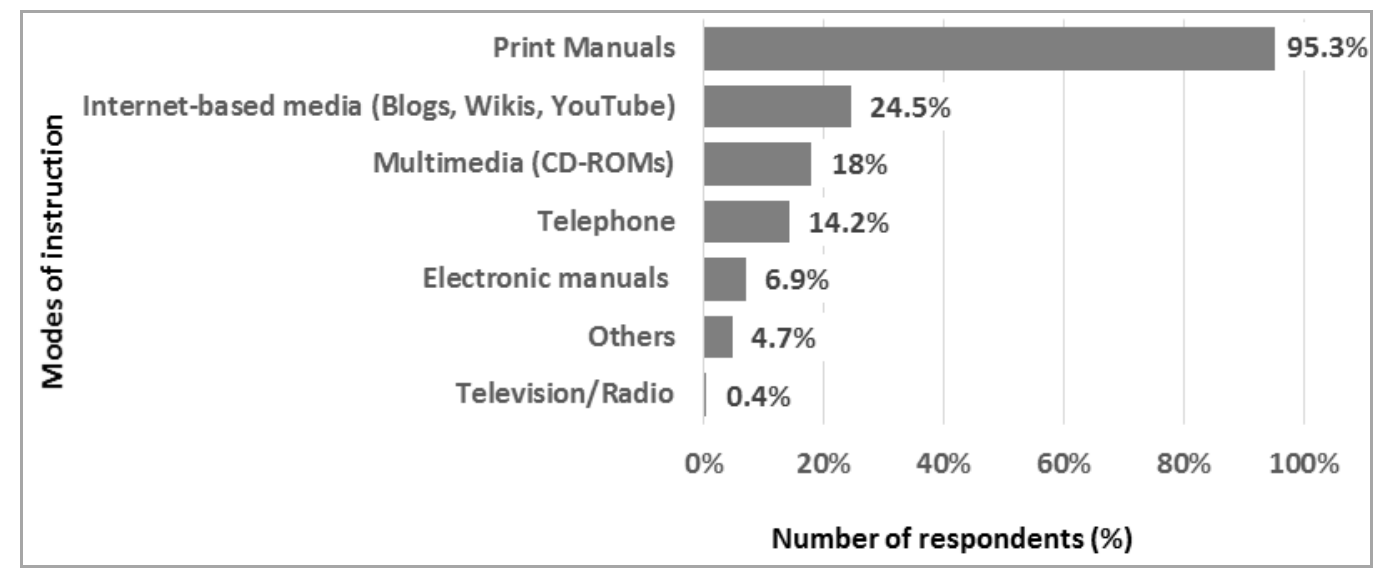

Figure 2. Modes of instruction. 
Findings further show that 203 (86.6\%) students preferred university learning manuals (instructional modules) mainly because of three reasons: they are cheap to access, they are comprehensive, and one does not need electricity to use them. Some verbatim from student respondents include: "we read even at our home in remote areas," "they are easily accessible and less expensive," "I am living in a very rural area where there is no electricity so it becomes convenient using print media," and I am able to read at my own pace and the records are permanent." Historically, print materials have remained the most popular learning materials in Malawi. This confirms what the TDT by Moore (1997) informing this study espouses by emphasising that taking into account that the learner may not meet the instructor, it is essential that courses should be well designed as if they are offered in a face-to-face environment. Thus, the fact that results show that students prefer print manuals because they are compressive signals that these learning manuals are well structured. Clarity and comprehensiveness of the learning print manual is a welcome development at MZUNI because, as Petroman and Petroman (2013) suggest, ODL materials should be structured in such a way that they completely replace the presence of the teacher, except for the final assessment and marking stages. Despite the popularisation of Internet and other electronic media in the past decade in Malawi (Chaputula, 2010), problems of electricity, especially in rural areas where most of these students live and the exorbitant prices for electricity, stymie the use of this digital media. However, the situation is different in Russia where Kudryavtseva (2014) reports that "effective and successful methods of self-study of a foreign language was attributed to many tutorials and special electronic educational resources delivered via the Internet” (p. 1217).

The study also established that the University employs two methods to assess its students: continuous assessment and end of semester examinations which the students come to write on campus. According to the findings, when students come to campus, they are also given take-home assignments that, upon completion, is submitted to the University by post or hand delivery. Many Heads of Department provided similar statements. One of them indicated that "students are assessed through written continuous assessment assignments (take home) and end of semester examinations taken right here on campus." The results suggest that the University follows an ODL model suggested by Holmberg (2005) who argues that "in other cases, supplementary face-to-face sessions can be useful for distance students" (p.14).

\section{Benefits of ODL}

Items in this section sought to establish the benefits of ODL programmes from a student and lecturers' perspective. All students indicated they had benefitted from the programme because it had accorded them an opportunity to access higher education which is affordable and flexible. As discussed in some of the previous sections, most of the students are currently working with the Ministry of Education, Science, and Technology as Primary School Teachers. The Ministry would not want to have its employees away from work for a long period of time (usually, they get disciplined or dismissed if they do) and this arrangement offers these students an opportunity to study while working. Students seem to be very excited to have accessed university education; most of the students provided similar comments as follows: "it has made me access university education after being left out by all universities in Malawi despite my good grades" and "with this programme, I am able to continue working, look after my family while doing my university education." 
Benefits mentioned by students were well supported by lecturers. For example, some statements coming from the Heads of Department included "[ODL] students study and work at the same time; they do not need study leave since most are teachers and are required on campus during recess," "It [ODL] promotes the right to education as some people who had no chance to attain university education can do so now," and "with unpredictable funding from Government, this is an ideal programme to bring education to most Malawians." Another lecturer commented that "students are usually in control of their learning activities as they decide when to study, write assignments and prepare for examinations; they are actually independent learners." Such moments uphold observations by Réka, et al. (2015) that distance learners have higher levels of autonomy, competence, and relatedness than full time learners. To this end, Kudryavtseva (2014) concluded that "it should be noted that distance learning is a process of selfeducation based on stand-alone courses, which do not involve regular interaction with the teacher (p. 1217). Moore (1997) refers to this as self-directness or autonomy; i.e., "the extent to which in the teaching/learning relationship, the learner rather than the teacher determines the goals, the learning experiences, and the evaluation decisions of the learning programme" (Moore, 1997).

The findings deepen what was observed some 13 years ago by the Commonwealth of Learning (2003) that open and distance learning has the potential to expand the limited number of places available for campusbased institutions which are few in numbers and have stringent entrance requirements. The findings also echo sentiments by Kudryavtseva (2014) who says distance learning offers opportunities for education outside the conventional system by providing flexibility in pursuing courses and taking examinations. Although Al-Arimi (2014, p.85) argues that distance education can be costly for students in some ways, findings of the current study show opposite results. According to students, tuition is affordable and the University offers a flexible way of paying such that some students responded that "making payments through instalments makes it easier for us who have lower levels of income," "to be honest, these fees are far much affordable as compared to what other colleagues pay in other universities," and "I have enough time to sort out financial issues while I am at home." Other students were of the view that studying as ODL students made them improve their teaching skills as evidenced by the following statement which represents many similar others; "as a secondary school teacher, I have improved in my delivery of lessons as I am able to explain some concepts which were difficult to explain before."

\section{Challenges Faced}

Although ODL programmes come along with various benefits as discussed in the preceding section, it is faced with a number of challenges. Thus, we asked participants to mention the challenges confronting the operations of ODL at MZUNI. According to Zirnkle (2001), most challenges emerge from three particular levels of, individual student, instructional, and institutional. As presented in Figure 3 below, most individual problems that students face include financial bad perception of ODL programmes, balancing family affairs with studying and unfriendly study environments at home. Although MZUNI offers affordable fees to these students, it still becomes difficult for them to pay because most of them have extended families to look after. Something worth noting is that these students do not receive loans from the government to help pay for their tuition, which may be the reason some of the students claim that they lack support from their employers (see Figure 3 below). Some Heads of Department also cited the problem of bad perception of ODL programmes, especially by the general public, such that one of them commented that "some people think that ODL students are half-baked just because they study on their 
own at home." The problem of bad perception of ODL has been reported in other studies such as those by Sherritt (1996), Commonwealth of Learning (2002), Wilson (2008), and Valentine (2002) who have all independently observed that some administrators, who are key decision makers, perceive ODL as second grade programmes. However, looking at the number of applications that the University receives, this is not a worrying problem, especially considering that the degree programmes offered are fully accredited by the Malawi Government.

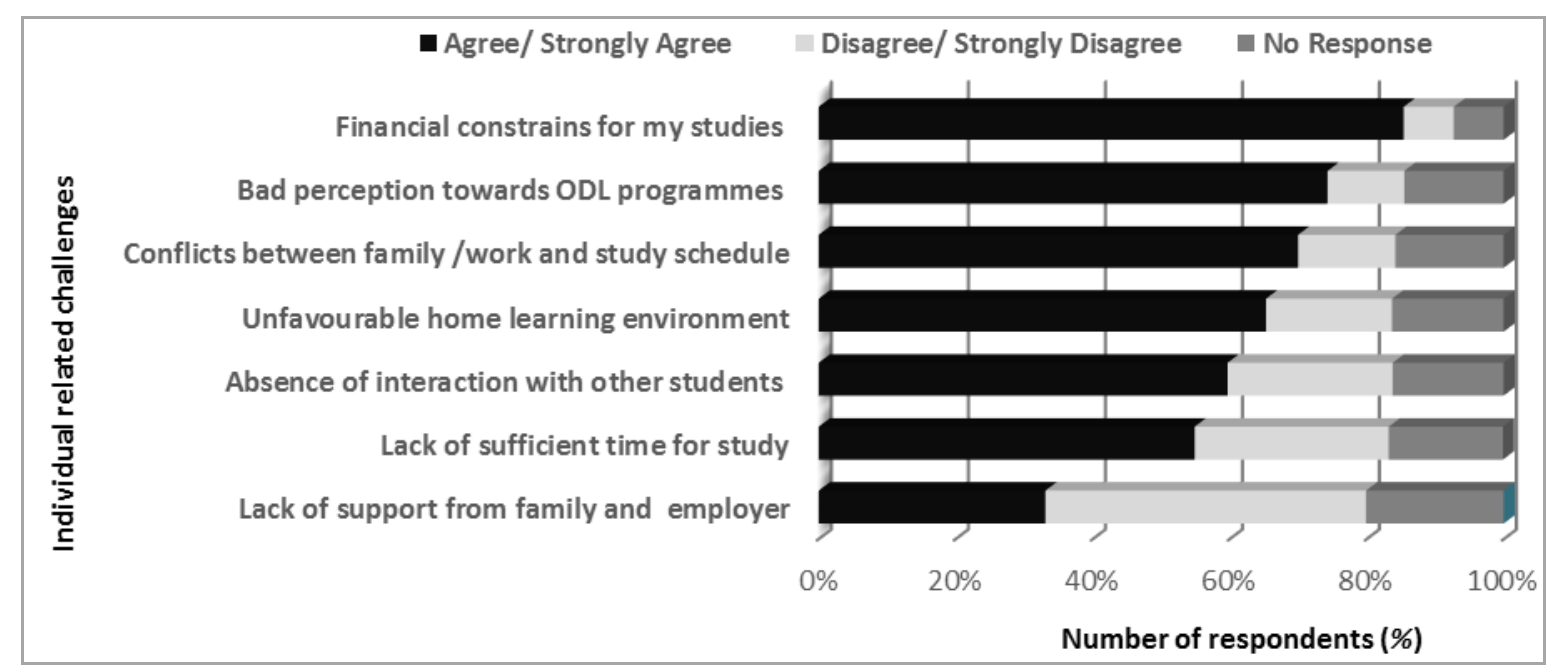

Figure 3. Challenges faced.

Instructional problems result from the fact that generally, ODL programmes are based on indirect teaching relationships between the lecturer and the learner who is a self-learner (Juma, 2005). As can be seen in Table 1 below, it is clear that the main problems include lack of academic support, delayed end of semester examination results, delayed feedback from instructors, and failure on the part of students to find information for their studies. Most students were so saddened with the perpetual delays in receiving end of semester examination results by the University with some students making the following statements: "I wonder why the University decides to commence the next semester before releasing results of the previous semester" and "It becomes devastating to learn you have been withdrawn from the University because of failing a course offered in the previous semester when you are already registered in the new semester; this demotivates us." From the Heads of Department perspectives, the study established three main problems: poor communication between CODL and departments, prolonged registration of students, and poor remuneration for lecturers. The problem of poor communication was highlighted by all Heads of Department, such that one of them commented that "communication between CODL and departments is not properly made; sometimes we learn things from students and we are forced to verify with the Centre."

The fact that only few students complained about poor learning materials or modules implies that the structure of instructional materials is flexible. This suggests that the designers of these learning materials took into account that learners could be learning without the intervention of instructors according to the Transactional Distance Theory (Moore, 1997). 
Delayed feedback from instructors is one of the aspects that is likely to affect the performance of ODL students according to Transactional Distance Theory (Moore, 1997). In this context, interpreting the results through the lens of Moore's (1997) Transactional Distance Theory, there is lack of interaction between learners and teachers or dialogue which this leads to negative effects on teaching/learning experiences. Using the Transactional Distance Theory (Moore, 1997) to measure how student interactions in online and blended learning environments impacted student learning outcomes, Ekwunife-Orakwue and Teng (2014) report similar findings that interaction with content is the core of distance learning, "which is why learner content interaction may be contributing to its exponential growth and the proliferation of open education movements" (Ekwunife-Orakwue \& Teng, 2014, p. 425). These findings substantiate observations by Kritpracha, Kaosaiyaporn, and Atisabda (2015) who place emphasis on the need to provide a learning platform that allows instructors and students to communicate without upheavals.

Table 1

Instructional Related Challenges

\begin{tabular}{|l|c|c|c|c|c|c|}
\hline \multirow{2}{*}{ Instructional related challenges } & \multicolumn{2}{|c|}{$\begin{array}{c}\text { Agree/ } \\
\text { Strongly } \\
\text { Agree }\end{array}$} & \multicolumn{2}{|c|}{$\begin{array}{c}\text { Disagree/ } \\
\text { Strongly } \\
\text { Disagree }\end{array}$} & \multicolumn{2}{c|}{$\begin{array}{c}\text { No } \\
\text { Response }\end{array}$} \\
\cline { 2 - 8 } & $\boldsymbol{f}$ & $\mathbf{\%}$ & $\boldsymbol{f}$ & $\mathbf{\%}$ & $\boldsymbol{f}$ & \% \\
\hline Lack of academic support & 181 & 77.6 & 24 & 10.3 & & 12.0 \\
\hline Delayed end of semester examination results & 176 & 75.5 & 25 & 10.8 & 32 & 13.7 \\
\hline Class too large & 173 & 74.3 & 26 & 11.2 & 34 & 14.6 \\
\hline Delayed feedback from instructors & 169 & 72.6 & 28 & 12 & 36 & 15.5 \\
\hline Failure to find relevant information for studies & 156 & 67 & 47 & 20.1 & 30 & 12.9 \\
\hline Poor learning materials/manuals & 77 & 33.1 & 109 & 46.8 & 47 & 20.2 \\
\hline Lost assignments and grades & 163 & 70 & 37 & 15.9 & 33 & 14.2 \\
\hline
\end{tabular}

In view of the problems highlighted in the preceding, several suggestions were provided by students on how MZUNI can address them. Between 156 (67\%) and 210 (90.1\%) respondents are of the view that the University should set up satellite centres in each district, should liaise with Government to offer soft loans to students, timely release of examination results and immediate feedback of assignments, the Centre should employ its own lecturers, offer accommodation to ODL students when they come for orientation, and advertise the ODL programmes using more media outlets other than just relying on newspapers. Most of the Heads of Department suggested that the University should recruit tutors and improve communication to the Departments. The study established that there is strong need to recruit tutors for Science courses as evidenced by a statement from one of the Heads of Department that reads: "ODL has the potential to reduce shortage of teachers but needs to be handled with care by recruiting tutors who can help students in carrying out experiments which are a must in Science related courses." These tutors could travel to the proposed satellite centres. The need for satellite centres has been emphasised before by AlArimi (2014) who argues that "distance education often requires establishment of regional centres" (p. 85). The satellite centres should be based on recommendation made by some researchers such as Mbatha and Naidoo (2010) who argue that such "centres should be equipped with technological resources such computers and Internet" (p.66). 


\section{Conclusions and Recommendations}

Our case study has demonstrated the potential of ODL programmes towards achieving universal access to higher education in Malawi, not just to the working group but to other many Malawians who cannot access it through campus-based learning. This is made a reality due to flexibility of the programme whereby students are allowed to study while working, and more importantly, tuition is fairly affordable, in addition to being paid through instalments. In a nut shell, the study finds that over the years, MZUNI has admitted quite a number of Malawians. Despite successes registered and benefits associated with the introduction of ODL programmes at MZUNI, the programmes are not short of challenges. Our study finds that delayed feedback from lecturers, delays in releasing end of semester results, and scarcity of study materials are the key instructional challenges cited by students. On the part of Heads of Department, challenges cited include poor communication from the Centre, poor remuneration, and prolonged registration of students when they come on campus. In light of the findings of the study, the researchers urge MZUNI to: release end of semester examinations on time to avoid inconveniencing learners, offer incentives to lecturers to motivate them provide feedback to learners on time, and to set up satellite learning centres in the three geographical regions of Malawi where students can access information materials, particularly electronic resources and where they can meet and interact with their colleagues and lecturers or tutors. We further urge MZUNI to improve communication between the Centre and lecturers, to offer competitive numeration to lecturers involved in teaching ODL students, and to speed up the process of registration for ODL students.

\section{Limitation of the Study and Areas for Further Research}

Being a case study implies that the findings cannot be generalised to other contexts. However, we envisage that our research findings will not only add value to the existing literature but rather, the innovative nature of the research topic implies that it will provide a model within which other researchers, especially in Malawi intending to conduct similar studies, will have to build on and interpret their findings though comparisons. To this end, we suggest that other researchers may conduct a comparative study by targeting two or more institutions of higher learning offering ODL programmes in Malawi. Particularly, an interesting study may address issues to do with challenges affecting access to information sources for ODL students.

\section{References}

Abimbola, A. E., Omolara, W.O.O., \& Fatimah, Y.T. (2015). Assessing the impact of open and distance learning (ODL) in enhancing the status of women in Lagos State. Procedia-Social and Behavioral Sciences, 174, 1512-1520.

Akintayo, M. O., \& Bunza, M. M. (2000). Perspectives in distance education. Bauchi, Nigeria: Ramadan Publishers.

Al-Arimi, A. M. A. K. (2014). Distance learning. Procedia-Social and Behavioral Sciences, 152, 82-88. 
Atkins, D. E., Brown, J. S., \& Hammond, A. L. (2007). A review of the open educational resources (OER) movement: Achievements, challenges, and new opportunities. Retrieved from http://www.hewlett.org/uploads/files/ReviewoftheOERMovement.pdf

Aslam, M. (2000). Education and training for millions: Pedagogical challenges for distance education. Open Learning, 15(3), 309-315.

Babbie, E. (2004). The practice of social research. Belmont, CA: Wadsworth.

Badat, S. (2004). Higher education and society in post-apartheid South Africa. In E. Allen \& S. Jeff (Eds.) Ten years on: Changing higher education in a changing world (pp. 2-6). The Open University: Milton Keynes.

Bekhradnia, B. (2004). 20 years of higher education policy in the United Kingdom: Looking back 10 years and forward to the next decade. In E. Allen \& S. Jeff (Eds.) Ten years on: Changing higher education in a changing world (pp. 11-21). The Open University: Milton Keynes.

Bitegeko, M. R. (2010). Challenges facing open and distance learning students: experiences from students of the Open University of Tanzania. (Unpublished master's thesis). Dodoma, Tanzania: University of Tanzania.

Bower, B. L., \& Hardy, K. P. (2004). From correspondence to cyberspace: Changes and challenges in distance education. New Directions for Community Colleges, 128, 5-12.

Braun, V., \& Clarke, V. (2006). Using thematic analysis in psychology. Qualitative Research in Psychology, 3(2), 77-101.

Brennan, J. (2004). The social role of the contemporary university: Contradictions boundaries and change. In E. Allen \& S. Jeff (Eds.) Ten years on: Changing higher education in a changing world (pp. 22-26). The Open University: Milton Keynes.

Chaputula, A. H. (2010). State, adoption and use of ICTs by students and academic staff at Mzuzu University, Malawi. Program: Electronic Library and Information Systems, 46(4), 364-382.

Chawinga, W. D. (2014). The use of Web 2.o in teaching and learning at Mzuzu University's Faculty of Information Science and Communications, Malawi (Unpublished master's thesis). Bellville, South Africa: Department of Library and Information Science, University of the Western Cape.

Chimpololo, A. (2010). The prospects and challenges of open learning and distance education in Malawi. World Academy of Science, Engineering and Technology, 6, 06-29.

Commonwealth of Learning. (2002). Distance education and open learning in Sub-Saharan Africa: A literature survey on policy and practice. Retrieved from https://www.col.org/resources/distanceeducation-and-open-learning-sub-saharan-africa-literature-survey-policy-and 
Commonwealth of Learning. (2003). Developing library and information services for distance education. Retrieved from http://oasis.col.org/bitstream/handle/11599/48/KS2003 library.pdf?sequence=1\&isAllowed=y

Connaway, L. S., \& Powell, R. R. (2004). Basic research methods for librarians (10th ed.). Greenwich, Conn: Libraries Unlimited.

Ekwunife-Orakwue, K. C., \& Teng, T. L. (2014). The impact of transactional distance dialogic interactions on student learning outcomes in online and blended environments. Computers \& Education, 78, 414-427.

Flyvbjerg, B. (2006). Five misunderstandings about case-study research. Qualitative Inquiry, 12(2), 219245.

Garrison, D. R. (2000). Theoretical challenges for distance education in the 21st century: A shift from structural to transactional issues. International Review of Research in Open and Distance Learning, 1(1), 1-16.

Goel, L., Zhang, P., \& Templeton, M. (2012). Transactional distance revisited: Bridging face and empirical validity. Computers in Human Behavior, 28(4), 1122-1129.

Gourley, B., \& Lane, A. (2009). Re-invigorating openness at the Open University: The role of open educational resources. Open Learning, 24(1), 57-65.

Greenberg, G. (1998). Distance education technologies: Best practices for K-12 settings. Technology and Society Magazine, IEEE, 17(4), 36-40.

Gwede, H. (2014). Challenges, opportunities and priorities for Malawi. Retrieved from www.col.org/about/.../Malawi Report.pdf

Holmberg, B. (2005). Theory and practice of distance education. UK, Routledge.

International Telecommunication Union. (2014). Transforming Africa: The promise of broadband. Retrieved from http://www.itu.int/en/ITUD/Conferences/connect/Documents/Post\%20Connect\%20Africa\%20 Summit\%20Report\%20(English).pdf

Juma, M. N. (2005). The establishment of a higher education open and distance learning knowledge base for decision makers in Kenya. Nairobi: Kenyatta University Press.

Kritpracha, C., Kaosaiyaporn, O., \& Atisabda, W. (2015). Expectation of educators and students towards a distance learning model in Southernmost Provinces of Thailand. Procedia-Social and Behavioral Sciences, 174, 2349-2354. 
Kudryavtseva, M.G. (2014). Possibilities of distance learning as a means of foreign language learning motivation among students of Economics. Procedia-Social and Behavioral Sciences, 152, 12141218.

Lentell, H. (2012). Distance learning in British universities: Is it possible? Open Learning: the Journal of Open, Distance and e-learning, 27(1), 23-36.

Lin, H. (2014). Contextual factors affecting knowledge management diffusion in SMEs. Industrial Management \& Data Systems, 114(9), 1415 - 1437.

Martindale, J. (2002). The cycle of oppression and distance education. Canada: Athabasca University.

Mbatha, B., \& Naidoo, L. (2010). Bridging the transactional gap in open distance learning (ODL): The case of the University of South Africa (Unisa). .Inkanyiso: Journal of Humanities and Social Sciences, 2(1), 64-69.

Moore, M. G. (1980). Independent study. In R. Boyd, \& J. Apps, (Eds.). Refining the discipline of adult education (pp. 16-31). San Francisco: Jossey-Bass.

Moore, M.G. (1997). Theory of transactional distance. Retrieved from http://www.aged.tamu.edu/research/readings/Distance/1997MooreTransDistance.pdf

Mzuzu University. (2014). Mzuzu university prospectus. Malawi, Mzuzu: Mzuzu University.

Mzuzu University. (2015). Annual report 2013/2014. Malawi, Mzuzu: Mzuzu University.

Perraton, H. (2000). Open and distance learning in the developing world. London: Routledge.

Petroman, C., \& Petroman, I. (2013). Improving the development of learning materials for open and distance learning. Procedia-Social and Behavioral Sciences, 83, 295-299.

Réka, J., Kármen, D., Susana, F., Kinga, K. J., Edit, M., \& Kinga, S. (2015). Implications of motivational factors regarding the academic success of full-time and distance learning undergraduate students: A self-determination theory perspective. Procedia-Social and Behavioral Sciences, 187, $50-55$.

Sherritt, C. (1996). A Fundamental problem with distance programs in higher education. Retrieved from http://eric.ed.gov/?id=ED389906

Smith, M.S., \& Casserly, C.M. (2006). The promise of open educational resources. Change, 38(5), 8-17.

Southern Africa Regional Universities Association. (2011). Towards a common future: Higher education in the SADC region. Retrieved from http://www.sarua.org/files/countryreports/CountryReportMalawi.pdf 
Swanepoel, E., De Beer, A., \& Muller, H. (2009). Using satellite classes to optimise access to and participation in first-year business management: A case at an open and distance-learning university in South Africa. Perspectives in Education, 27(3), 311-319.

Teaster, P., \& Blieszner, R. (1999). Promises and pitfalls of the interactive television approach to teaching adult development and aging. Educational Gerontology, 25(8), 741-754.

The United Nations Educational, Scientific and Cultural Organisation (UNESCO). (2003). Gender and education for all: The leap to equality. Paris: UNESCO Publishing.

United Nations Development Programme (UNDP) Human Development Report. (2014). Sustaining human progress: Reducing vulnerabilities and building resilience. Washington DC: Communications Development Incorporated.

The United Nations. (1948). The universal declaration of human rights. Retrieved from http://www.ohchr.org/EN/UDHR/Documents/UDHR Translations/eng.pdf.

The United Nations. (1966). International covenant on economic, social and cultural rights. Retrieved from http://www.ohchr.org/Documents/ProfessionalInterest/cescr.pdf.

Valentine, D. (2002). Distance learning: Promises, problems, and possibilities. Retrieved from http://www.westga.edu/ distance/ojdla/fall53/valentine53.html.

Wilson, T. (2008). New ways of mediating learning: Investigating the implications of adopting open educational resources for tertiary education at an institution in the United Kingdom as compared to one in South Africa. The International Review of Research in Open and Distance Learning, 9(1), 1-19.

Zirnkle, C. (2001). Access barriers in distance education. Contemporary Education, 72(2), 39-42.

\section{Athabasca} University

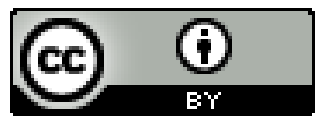

